\title{
Implicações da Saúde Humana e Ambiental decorrentes da presença de Pombos no ambiente Urbano
}

\author{
SEABRA, Eneyda Cristina Mourão ${ }^{[1]}$, OLIVEIRA, Euzébio de ${ }^{[2]}$
}

SEABRA, Eneyda Cristina Mourão. OLIVEIRA, Euzébio. Implicações na saúde humana e ambiental decorrentes da presença de pombos no ambiente urbano. Revista Científica Multidisciplinar Núcleo do Conhecimento. Ano 01, Ed. 05, Vol. 02, pp. 106-128, Maio de 2016. ISSN:2448-0959

\section{RESUMO}

A pesquisa foi realizada na Escola Estadual "D. Helena Guilhon", situada no Conjunto Satélite, analisando a presença do pombo doméstico (Columba lívia domestica), seu comportamento e distribuição na escola. Analisaram-se também os possíveis problemas na saúde humana e ambiental que essa espécie pode causar, quando em grande quantidade, bem como as medidas de controle e métodos de prevenção. Foram realizados registros fotográficos para demonstrar o contato direto que essas aves têm com alunos e demais pessoas da escola. Também foram analisados os possíveis danos ao patrimônio ocasionados pelas fezes desses animais. Foram realizadas entrevistas para reconhecimento da concepção dos alunos com relação aos pombos. Para mudanças de hábitos dos alunos na escola foram realizadas palestras de esclarecimento a respeito dos problemas ocasionados. Verificou-se intensa presença e atividade da espécie na escola. Atualmente o número de pombos é grande, e percebemos que os fatores que fazem com que estes se proliferem no local são: fartura de alimentos, água e bons locais para reprodução.

Palavras-chaves: Pombos, escola, doenças, prevenção

\section{INTRODUÇÃO}

Os pombos são aves da ordem Columbiformes da família Columbidae e gênero Columba que apresenta mais de 50 espécies no mundo todo e uma grande diversidade quanto à cor da plumagem, tamanho e hábitos. O pombo doméstico (Columbia lívia domestica) não é uma ave nativa das Américas. São consideradas três variedades de pombos: Pombo das Rochas, Pombo Doméstico e Pombo Urbano. O Pombo Urbano é descendente dos Pombos Domésticos que fugiram dos cativeiros e procriaram-se. Ele originou-se da Europa, norte da África, Oriente Médio e Ásia, foi introduzido no Brasil por ordem de D. João VI com o objetivo de enfeitar as cidades. Uma vez retirado de seu habitat natural e introduzido no 
ambiente urbano, essas aves perderam o comportamento das espécies nativas, sendo consideradas exóticas (NUNES, 2003).

Para muitas pessoas os pombos são aves que simbolizam a paz e são muito utilizadas em eventos públicos e religiosos, pois representam o Divino Espírito Santo. Os pombos, assim como outras aves, são admirados pela sua delicadeza e beleza. Além dos valores simbólicos, os pombos foram muito utilizados como mensageiros ou para carregar câmeras espiãs, principalmente nas duas grandes Guerras Mundiais. Apresentam também importância na culinária de alguns países europeus (THOMAS, 1988).

Hoje os pombos são encontrados em muitas cidades e também na zona rural. Em muitos países os pombos fazem parte da paisagem do local como na Praça de São Marco (Veneza), na Praça de Trafalgar (Londres), na Praça Jackson (Nova Orleans). Sendo muitas vezes um atrativo para moradores e turistas que visitam esses locais. No Brasil também são encontrados em praças e outros locais como na Praça da Bandeira (Campina Grande) e em Belém, segundo Roberto Brito (Centro de Zoonoses), os pontos de maior concentração desses animais são o centro comercial, a área do Ver-o-Peso, a Praça da República, além de escolas e condomínios, onde há grande oferta de alimento. E sendo aves que fazem parte dessas paisagens, muitas pessoas que passam ou moram nas proximidades, jogam alimentos atraindo um número cada vez maior para o local. O pombo doméstico se adaptou muito bem nas áreas urbanas pela facilidade de alimento e abrigo (NUNES e MIRANDA, 2010).

Esses animais medem aproximadamente $38 \mathrm{~cm}$, são muito resistentes e possuem um espantoso censo de direção. Alimentam-se basicamente de grãos, como milho, cevada e aveia, mas se adaptam facilmente aos restos de alimentos que encontram como farelo de pão, feijão e arroz. Por esse e outros motivos são chamados popularmente como "ratos de asas" (NUNES e MIRANDA, 2010).

Quanto à reprodução, os pombos são monogâmicos. O ciclo reprodutivo dessas aves é regulado pela disponibilidade de alimento. Em centros urbanos o pombo doméstico realiza a reprodução o ano todo, com exceção na época de muda das penas. Normalmente a fêmea coloca dois ovos, aproximadamente 12 dias após a cópula e ocorre a incubação por um período de 17 dias (NUNES, 2003; NUNES e MIRANDA, 2010).

Os pombos domésticos permanecem próximos de habitações humanas, podendo causar sérios transtornos, pois danificam vários tipos de estruturas com suas fezes que são ácidas. Em estudos realizados em alguns estados brasileiros, verificou-se que em locais que servem de abrigo a esses pássaros, como torres de igreja, altos edifícios, telhados de casas e escolas, há um alto índice de fungos, encontrados principalmente nas fezes, que permanecem viáveis à infecção por um período de até dois anos, ocasionando diversas doenças como a criptococose, histoplasmose, ornitose, salmonelose e alergias. Causam também problemas com relação a ectoparasitas como piolhos, ácaros e pulgas (NUNES e MIRANDA, 2010).

Segundo Bencke (2007), em muitos lugares o pombo-doméstico já atingiu a condição de praga urbana, em razão de sua superpopulação, dos prejuízos econômicos que causa e dos riscos que representa à saúde pública, sendo necessário o controle populacional. Portanto, é necessário alertar a população sobre seu papel de co-responsável pela proliferação dessas aves, pois algumas atitudes colaboram para a manutenção da vida desses animais em ambientes urbanos e o presente trabalho teve como objetivo analisar as implicações na saúde humana e ambiental decorrentes da presença de pombos no ambiente 
escolar.

\section{METODOLOGIA}

O presente trabalho foi realizado em diferentes etapas. No primeiro momento foram aplicados questionários contento questões de diagnose referente à presença de pombos no ambiente escolar. Este contemplou alguns pontos como: concepção dos alunos com relação à presença das aves na escola, grau de consciência sobre as possíveis doenças relacionadas aos pombos, e se os mesmos possuíam atitudes que contribuíam para a permanência desses animais sinantrópicos no ambiente escolar. Feito o trabalho de análise sobre o nível de conhecimento dos alunos sobre o tema, partimos para o segundo momento.

As informações obtidas pela aplicação dos questionários e pelas entrevistas serviram de subsídios para a criação de gráficos.

Na segunda etapa metodológica foram selecionadas duas turmas do $2^{\circ}$ ano do Ensino Médio dos turnos da manhã e da tarde para realizarem pesquisas referentes às doenças ocasionados pelos pombos, bem como os modos de prevenção e limpeza dos locais onde as aves se estabelecem. Foram realizadas vistorias pelos alunos na escola para observação de possíveis ninhos e ambientes mais frequentados pelos pombos, além disso, avaliaram o nível de degradação da escola decorrente das fezes dos pombos, que são ácidas. Paralelamente foram retiradas fotos desses locais para posterior demonstração.

Esses alunos realizaram palestras para as outras turmas da manhã e da tarde e para o pessoal da limpeza e da copa, contribuindo assim para alcançar os objetivos do trabalho.

$\mathrm{Na}$ última etapa do trabalho realizamos conjuntamente com os alunos a organização de uma panfletagem no entorno da escola a fim de divulgar os conteúdos trabalhados no projeto, objetivando assim o esclarecimento da população sobre os riscos e possíveis prevenções a respeito das doenças causadas pelos pombos.

\section{ÁREA DE ESTUDO}

O presente trabalho foi realizado na Escola Estadual de Ensino Fundamental e Médio "Dona Helena Guilhon", situada no Conjunto Satélite, WE - 5 S/N, bairro Coqueiro.

A escola foi fundada em 1974, através do Decreto n 9.495, no governo de Fernando José Leão Guilhon, e inaugurada em 19 de março de 1975. Seu nome foi uma homenagem a genitora do então Governador do Estado do Pará.

Criada para atender a comunidade do Conjunto Satélite, construída basicamente por servidores do Estado, atualmente recebe alunos de várias comunidades circunvizinhas como: Ariri, Sideral, Sevilha e outras mais longínquas.

Quando de sua fundação, contava com apenas 05 (cinco) salas de aula e 03 (três) dependências. Atualmente, possui 19 salas de aulas e outras dependências.

A escola consta de três blocos de salas de aula. Além desses blocos, possui o bloco da direção e sala dos 
professores, a área da cantina e alimentação dos alunos e o bloco dos laboratórios de informática e multidisciplinar. Estes dois últimos foram fundados no ano de 2008 e observou-se a ausência de pombos já que são prédios relativamente novos.

\section{RESULTADOS E DISCUSSÃO}

\section{RELAÇÃO HOMEM-POMBO}

Fazendo-se uma abordagem histórica sobre a relação do homem com os animais domesticados, percebese que a partir do final do século XVI começaram os primeiros movimentos em respeito aos animais, já que antes eram comuns atitudes de crueldade contra estes, inclusive crianças torturavam criaturas vivas sem qualquer pesar (THOMAS, 1988).

A partir de então aos poucos se foi criando uma concepção de respeito aos animais, tentando até mesmo algumas medidas de proteção às espécies em ameaça de extinção. Nesse contexto, no início do período moderno, foi crescente a preocupação com teorias ambientais, já que com o início da industrialização na Inglaterra observa-se a crescente apropriação dos recursos naturais sem qualquer preocupação futura, ocasionando, após décadas, a escassez de alguns desses recursos e problemas ambientais graves (SILVA, 2006).

Devido a essa problemática ambiental, a partir das décadas de 60 e 70 começou o despertar em parte da população dos países desenvolvidos, o interesse pelas questões das condições de alteração do ambiente natural do planeta. Paralelamente ocorreu a preocupação cada vez maior com a defesa dos animais, tanto os domesticados quanto os utilizados a serviço da humanidade (SILVA, 2006).

Diferentes posicionamentos se têm a respeito dos pombos urbanos. Desde a antiguidade essas aves eram utilizadas por governantes como transmissores de mensagens, chegando até mesmo no Império Persa a dar origem a um ramo da Administração Pública. Na Primeira Guerra Mundial foram utilizados mais de 30.000 pombos-correios nas frentes de combate. Essa estreita relação dos pombos com os seres humanos perdura até hoje havendo uma incorporação dessas aves à paisagem de praças e parques de várias cidades, sendo comum, as pessoas admirarem e alimentá-las sem qualquer percepção dos riscos à saúde que podem causar (VALADARES, 2004).

Paralelo ao posicionamento da maioria da população, em que o pombo somente é visto como um animal belo e inofensivo, símbolo de pureza e paz, tem-se a posição de médicos infectologistas que alertam sobre os riscos do contato direto com essas aves, seja em praças, parques, em escolas ou aos columbófilos, que são os criadores de pombos (NUNES e MIRANDA, 2010).

\section{DOENÇAS PROVOCADAS POR POMBOS}

\section{1 - CRIPTOCOCOSE}

O Cryptococcus neoformans, é um fungo leveduriforme, capsulado encontrado geralmente em solos contaminados com fezes de pombo. É um dos agentes etiológicos da criptococose, que é uma micose grave que ocorre preferencialmente em indivíduos imunocomprometidos. A infecção ao homem se dá pelo contato com pombos ou através da inalação de propágulos do ambiente na forma de leveduras. Os sintomas geralmente são febre, dor torácica, hemoptise, massa granulomatosa (nódulos únicos ou 
múltiplos no Rx), pápulas e abcessos na pele, com posterior ulceração, dor de cabeça, rigidez na nuca, distúrbios visuais, meningite cripotocócica (quase sempre fatal se não tratada adequadamente) (FARIA et al., 2010).

O Cryptococcus neoformans tem a capacidade de colonizar a mucosa do papo dos pombos sem causar doença, devido à alta temperatura de seu corpo, sendo parasita natural dessas aves. Esses animais sendo assintomáticas são vistas sempre como saudáveis pelas pessoas que as criam ou simplesmente as alimentam. Sendo assim, dificulta um possível diagnóstico ou tratamento, aumentando a possibilidade de transmissão às pessoas que entram em contato com essas aves (QUEIROZ et al., 2008).

Nota-se, em vários relatos médicos, a associação da criptococose com pacientes que são acometidos da síndrome da imunodeficiência adquirida (AIDS), sendo que na grande maioria é confirmada a presença de pombos ao redor da residência dos pacientes. Esse agente oportunista, infecta também leucêmicos, transplantados, portadores de tumores, entre outros (FARIA et al., 2010).

A forma meningoencefálica de criptococose é a mais freqüente, por isso, é muito importante o diagnóstico precoce para se evitar uma possível morte decorrente desse patógeno.

\section{2 - HISTOPLASMOSE}

A histoplasmose é uma infecção causada por um fungo dimórfico, o Histoplasma capsulatum. Este fungo apresenta forma filamentosa em temperatura inferior a $30^{\circ} \mathrm{C}$, composta de hifas hialinas, microconídios e macroconídios. Tem sido encontrado em fezes de aves e morcegos e crescem bem em solos com alto teor de nitrogênio (CURY et al., 2001).

A infecção pelo fungo Histoplasma capsulatum acontece principalmente através da inalação de propágulos suspensos no ar, afetando a via pulmonar, podendo causar infecções assintomáticas ou não. Todas as manifestações clínicas são semelhantes à tuberculose, por isso é necessário um exame mais detalhado, principalmente laboratorial. Em um hospedeiro saudável, geralmente a infecção é assintomática, mas esse fungo surge como um patógeno oportunista em pacientes transplantados, leucêmicos, usuários de antibióticos e principalmente em pacientes com a Síndrome da Imunodeficiência Adquirida (AIDS) (UNIS et al., 2004).

\section{3 - ORNITOSE}

A ornitose é causada pela bactéria intracelular obrigatória gram-negativa Chlamydia psittacie caracterizase por doença de início com sintomas brandos e inespecíficos como febre, cefaleia, mialgia (dores musculares), calafrios e tosse, igualmente a infecções das vias aéreas superiores, sendo difícil diferenciar de uma pneumonia causada por outros agentes patogênicos. O diagnóstico precoce é muito importante, pois a doença pode evoluir e levar o paciente à morte. Essa doença foi primeiramente relatada em 1893 por Morange que descreveu um agente infeccioso transmitido por papagaios. Hoje se sabe que os seres humanos são infectados através da inalação do microrganismo Chlamydia psittaci, quando em contato com pássaros infectados (MOSCHIONI et al., 2001).

Em vários casos de contaminação por essa bactéria, descritos pela medicina, um deles ocorreu em MedinaMG. Um estudante de 16 anos esteve internado com quadro de tosse seca, febre alta, mal-estar, mialgia, 
dor abdominal difusa, entre outros sintomas. O quadro clínico do paciente teve uma progressiva piora tendo que ser submetido à intubação no Centro de Terapia Intensiva (CTI). Foi relatado através de seus familiares que o referido jovem fazia criação de pombos. Diante do exposto, foi colhida secreção traqueal e constatado a presença de Chlamydia psittaci. Após o devido tratamento com medicação apropriada e internação de 23 dias, o paciente apresentava-se em bom estado de saúde. Portanto, constata-se que essa bactéria é transmitida aos seres humanos principalmente através do contato com pássaros entre eles os pombos domésticos. A Chlamydia psittaci excretada em grande número nas fezes, urina, secreções, saliva e penas (MOSCHIONI et al., 2001).

\section{4 - SALMONELOSE}

Salmonelas são bacilos gram-negativos que podem residir no trato intestinal de diversos mamíferos, aves e répteis. Em aves adultas a salmonelose é assintomática, mas secretam continuamente a Salmonellapelas fezes. O primeiro relato de salmonelose em aves foi no século passado em um surto de enterite em pombos (SILVA, 2004).

Estudos atuais têm indicado, que a maior fonte de infecção de Salmonella para o homem são as aves domésticas, como os pombos. Essa bactéria causadora da salmonelose normalmente coloniza o sistema gastrointestinal de certos animais, por isso, a principal forma de infecção se dá através das fezes, ou seja, pela extrema falta de higiene no ato da manipulação de alimentos (NUNES, 2003).

\section{MEDIDAS DE PREVENÇÃO E CONTROLE}

A população de pombos de um local aumenta através de nascimentos e migrações. O tempo de procriação dessas aves é relativamente curto e cada casal procria cerca de cinco vezes por ano, gerando cerca de 40 filhotes em cinco anos, que é o tempo médio de vida dessas aves em centros urbanos. Essa taxa de reprodução aumenta consideravelmente com a abundância de alimentação. Portanto, uma das mais eficazes medidas de controle dessas verdadeiras pragas urbanas, seria evitar alimentá-los, pois assim se afastariam do local, deslocando-se a procura de alimento. Outras medidas de controle eficazes são a restrição aos locais de abrigo e reprodução. É de extrema importância a vedação dos espaços onde os pombos se instalam e podem ser realizados através de telas de plástico, tapumes ou argamassa (NUNES e MIRANDA, 2010).

Algumas medidas podem ser aplicadas para se evitar o pouso dos pombos nesses locais onde se alojam e se reproduzem. Uma delas é a instalação de hastes pontiagudas tipo "porco espinho" (BENCKE, 2007). Além disso, podem-se instalar fios de nylon nos locais de pouso, como mostra a figura abaixo, pois causam sensação de instabilidade para os pombos, provocando seu afastamento. 


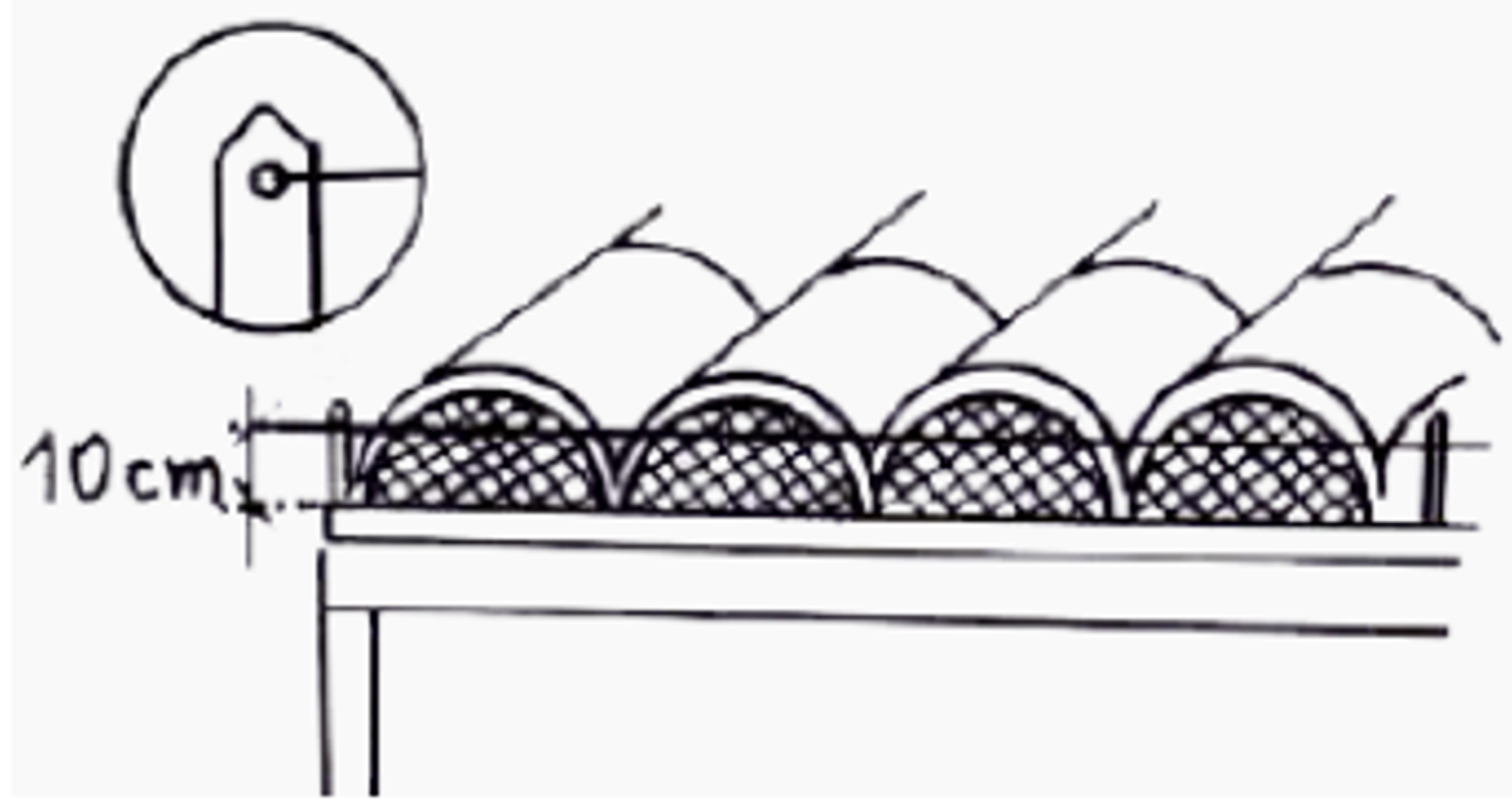

Fonte: Cartilha Manejo de Pombos Urbanos

Pode-se também fazer o uso de repelente para pássaros, que é um produto à base de polisobutileno espessante, que afasta esses animais do local. As palestras educativas também são de extrema importância já que para o afastamento total dos pombos da escola as medidas tomadas devem ser contínuas, como a limpeza dos locais de lanche dos alunos e eliminação das fontes de água e alimentação (VALADARES, 2004).

Uma citação que se destaca, feita pelo médico veterinário do Centro de Zoonoses do Município de Belém, Roberto Brito (2010), faz a seguinte referência:

São dois critérios básicos que impedem os pombos de se instalarem em áreas urbanas: um é não dar alimentos e o outro é não oferecer abrigo a eles. Além dos prejuízos à saúde ainda tem os transtornos que eles podem gerar como entupimento de calhas pelas fezes e o incômodo com o arrulho, que é o barulho emitido pelo animal (BRITO, 2010, p. 01).

A limpeza dos locais onde haja acúmulo de fezes de pombos deve ser utilizada com cuidado, já que são elementos de propagação de microrganismos causadores de diversas doenças. Recomenda-se que a limpeza deve ser feita através do umedecimento das fezes com água, água sanitária ou outro desinfetante. É também imprescindível a utilização de máscaras e luvas, já que algumas das doenças são causadas pela inalação dos microrganismos (VALADARES, 2004).

Após a higienização é recomendado a desinsetização do local, já que os pombos são portadores de ectoparasitas como piolhos, ácaros e carrapatos. O emprego de substâncias anticoncepcionais é considerado uma medida de controle com médio ou longo prazo. Essa substância inibe a reprodução das aves. 
Em alguns aeroportos são utilizados falcões, que são os predadores naturais dos pombos, afastando-os do local, evitando assim graves acidentes com aeronaves (NUNES e MIRANDA, 2010).

\section{PROTEÇÃO AMBIENTAL}

Os pombos por estarem amplamente adaptados ao ambiente urbano são considerados animais pertencentes à fauna silvestre brasileira e como tal são protegidos por lei federal de proteção à fauna. De acordo com o IBAMA, são espécimes da fauna silvestre todos aqueles pertencentes às espécies nativas, migratórias e quaisquer outras, que tenham todo ou parte de seu ciclo de vida ocorrendo dentro dos limites do território brasileiro.

Segundo a Instrução Normativa IBAMA Nº 109, de 03/08/2006, as medidas de manejo só poderão ser realizadas por pessoas devidamente autorizadas e quando as possibilidades de controle já tiverem sido esgotadas, como eliminação do acesso aos abrigos e fontes de alimentação. Caso contrário, qualquer atitude que configure danos físicos ao animal, sofrimento ou apreensão pode ser considerada crime passível das penas previstas em lei.

A Lei 9.605 de 12/02/98 do IBAMA em seu Artigo 29 dita que matar, perseguir, caçar, apanhar, utilizar espécimes da fauna silvestre, nativos ou em rota migratória, sem a devida permissão, licença ou autorização da autoridade competente, poderá sofrer pena de detenção de seis meses a um ano, e multa.

\section{ESTUDO DE CAMPO}

No dia 14 de dezembro de 2010 , os alunos do $2^{\circ}$ ano do turno da manhã fizeram uma vistoria pela escola para analisar os locais em que havia maior incidência de pombos, ou seja, quais os locais onde essas aves costumam se alojar e reproduzir. Essa mesma vistoria foi realizada no dia 16 do mesmo mês, pelos alunos do $2^{\circ}$ ano do turno da tarde.

Neste dia os alunos fizeram registros fotográficos e perceberam que os espaços onde existe maior presença de pombos são nos blocos das salas de aula e no bloco onde funciona a cantina e área de lanche dos alunos, como mostra a figura 1 A e pelos corredores da escola (Figura $1 \mathrm{~B}$ ). Perceberam a intensa presença das aves após o intervalo, já que se alimentam dos restos de lanche que ficam expostos no chão, jogados pelos próprios alunos. 
Revista Científica Multidisciplinar Núcleo do Conhecimento - RC: 2712 - ISSN: 2448-0959

https://www.nucleodoconhecimento.com.br/saude/saude-na-presenca-de-pombos

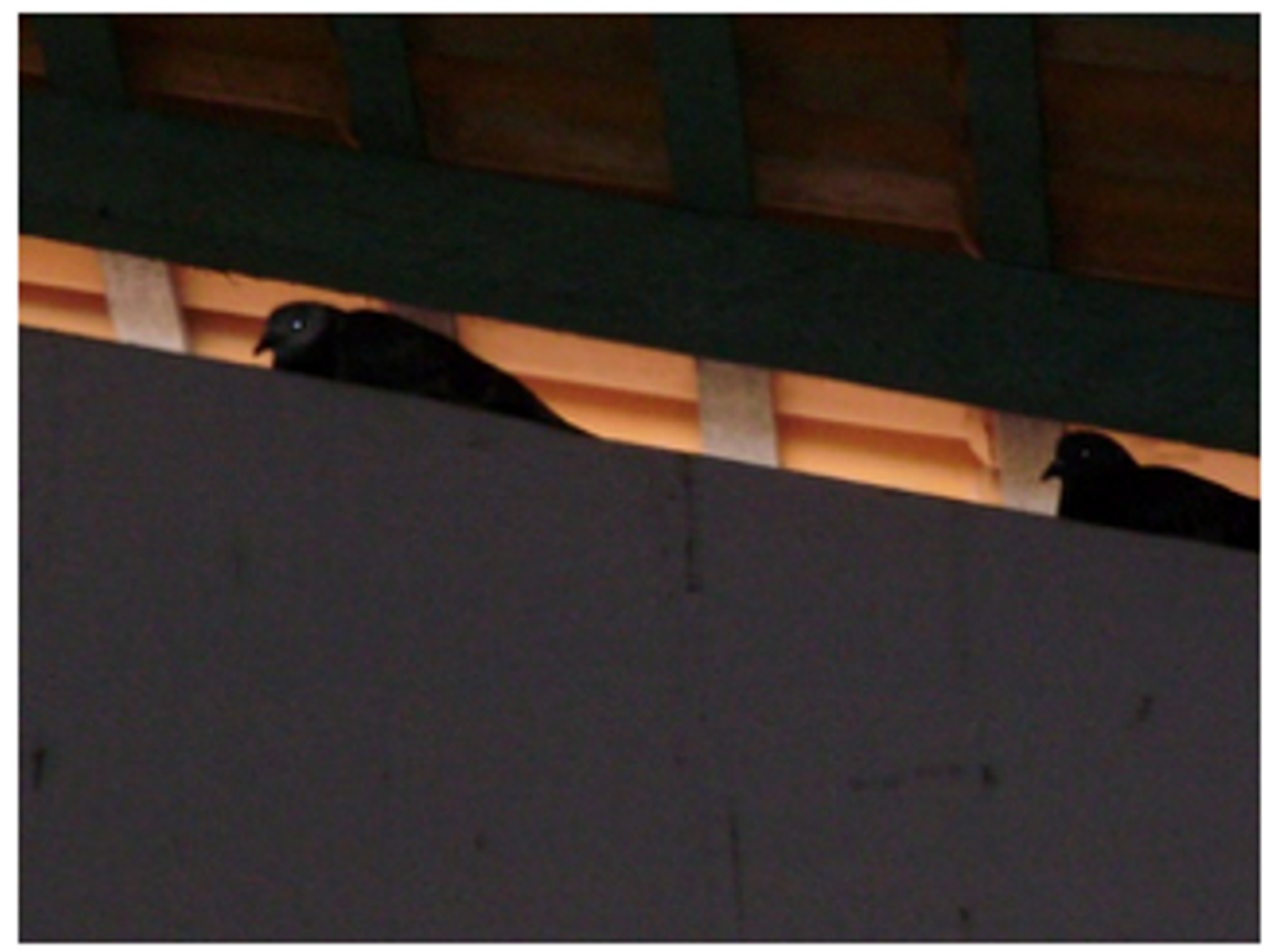

Figura 1 A : Pombos no telhado e na Área da Cantina. 


\section{Revista Científica Multidisciplinar Núcleo do Conhecimento - RC: 2712 - ISSN: 2448-0959}

https://www.nucleodoconhecimento.com.br/saude/saude-na-presenca-de-pombos

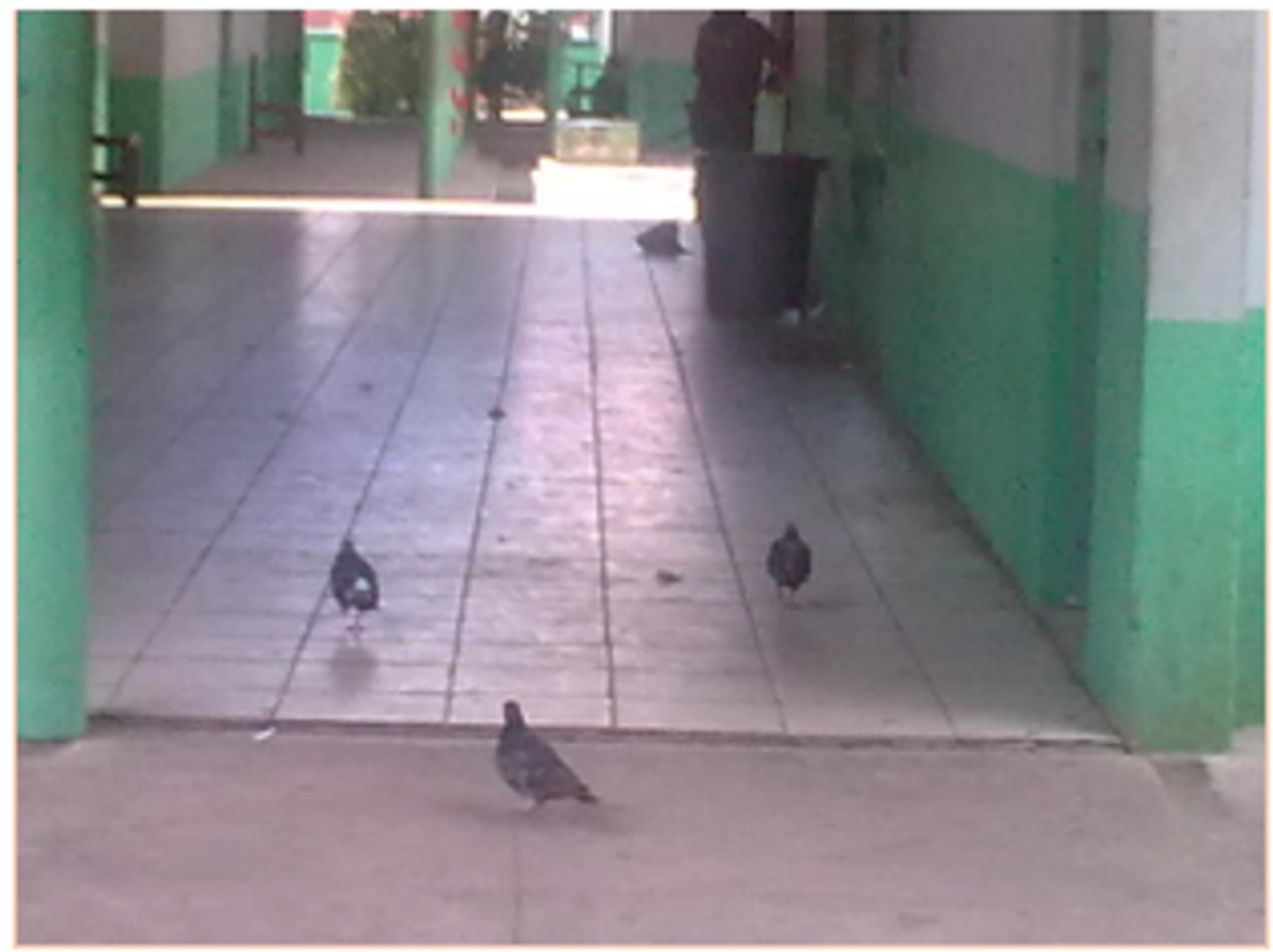

Figura 1 B: Pombos nos corredores da Escola.

A escola passou por uma reforma que teve inicio no ano de 2007 e foi concluída em 2009, mas os alunos perceberam que em algumas salas de aula os pombos conseguiram ter acesso ao forro, já que estavam abertos (Figura 2). Situação semelhante constatada por Nunes e Miranda (2010) na Universidade de Cuiabá - UNIC. 


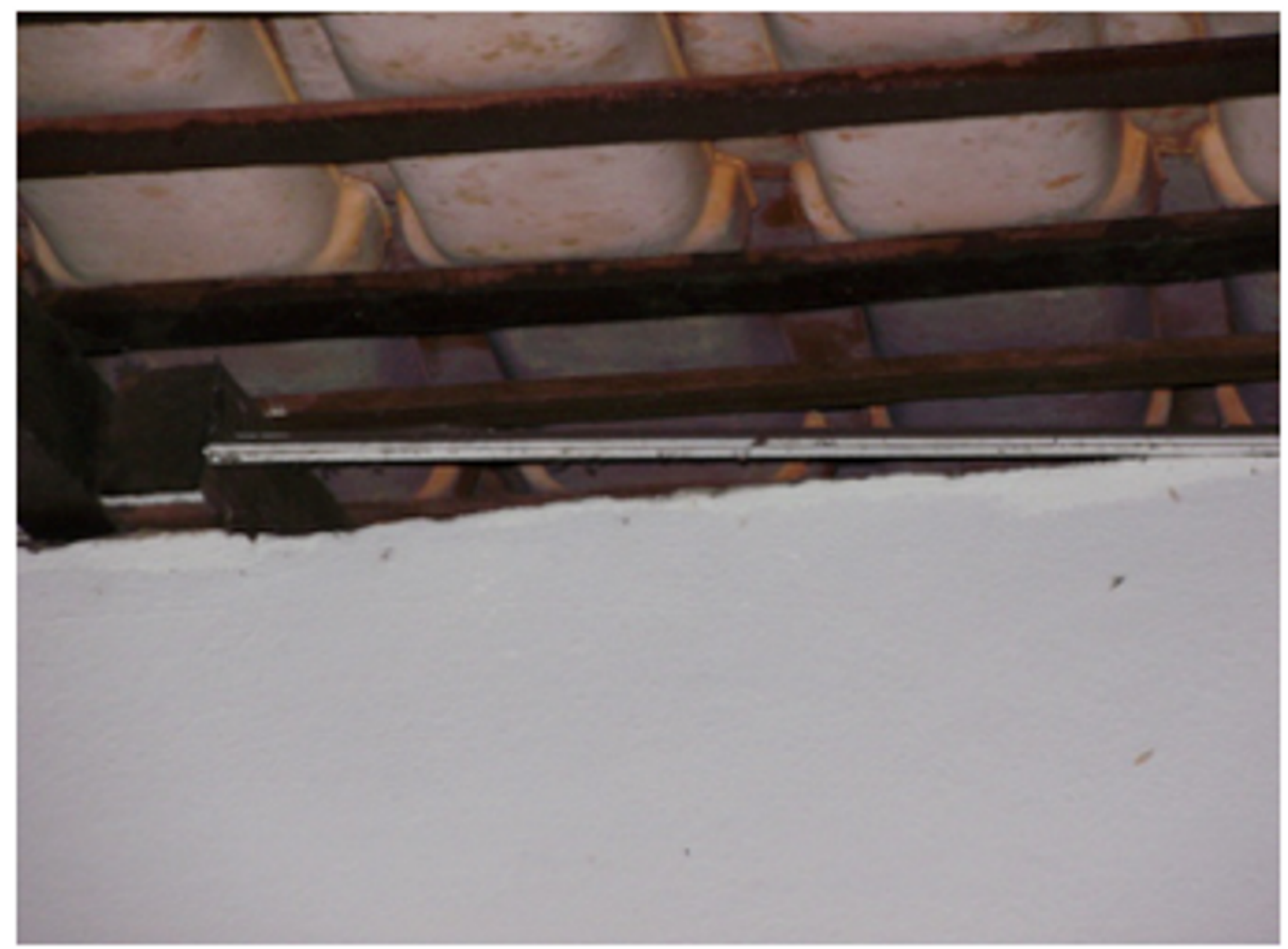

Figura 2: Vedação do forro de sala de aula quebrado.

$\mathrm{Na}$ inspeção que os alunos fizeram no bloco da direção, observaram que é pequena a presença de pombos neste local. Perceberam apenas que alguns pousavam nas caixas de ar condicionado para a obtenção de água. As mesmas conclusões chegaram no bloco dos laboratórios de informática e multidisciplinar. Esse bloco é relativamente novo, construído no ano de 2008, e os espaços de acesso ao forro foram vedados, impedindo assim a entrada dos pombos no local.

No dia 06 de janeiro de 2011, os alunos observaram a presença de um ninho em uma coluna próximo a uma das salas de aula. Perceberam que esse ninho havia sido construído recentemente (Figura 3). 


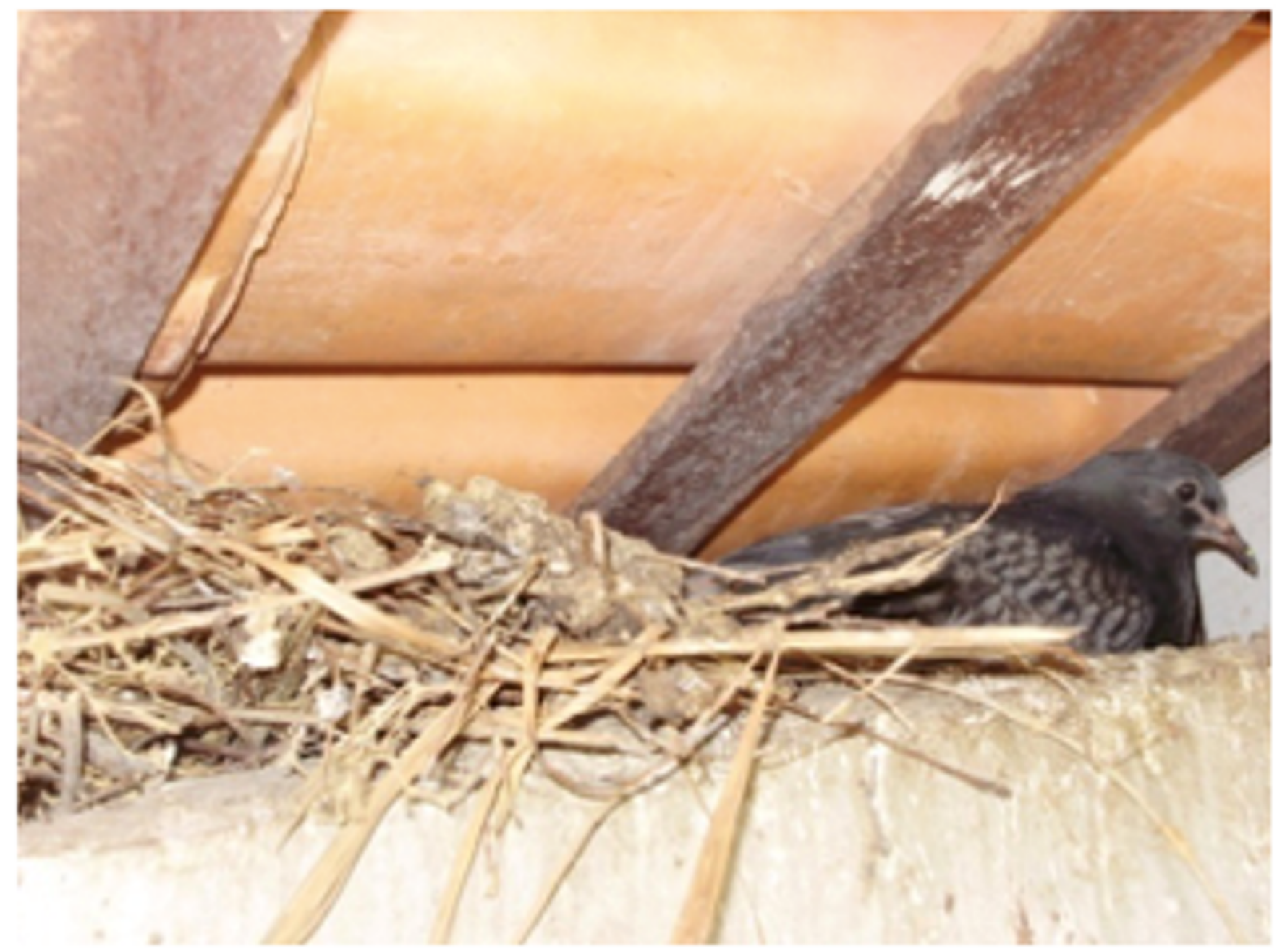

Figura 3: Ninho de pombo em coluna próxima a sala de aula.

Dando continuidade, os alunos observaram o intenso acúmulo de fezes nas paredes próximas às salas de aula e na área da cantina. Fator preocupante, já que as fezes dos pombos são ácidas e danificam a pintura da escola e outros materiais. (Figura 4 A e B). 
A

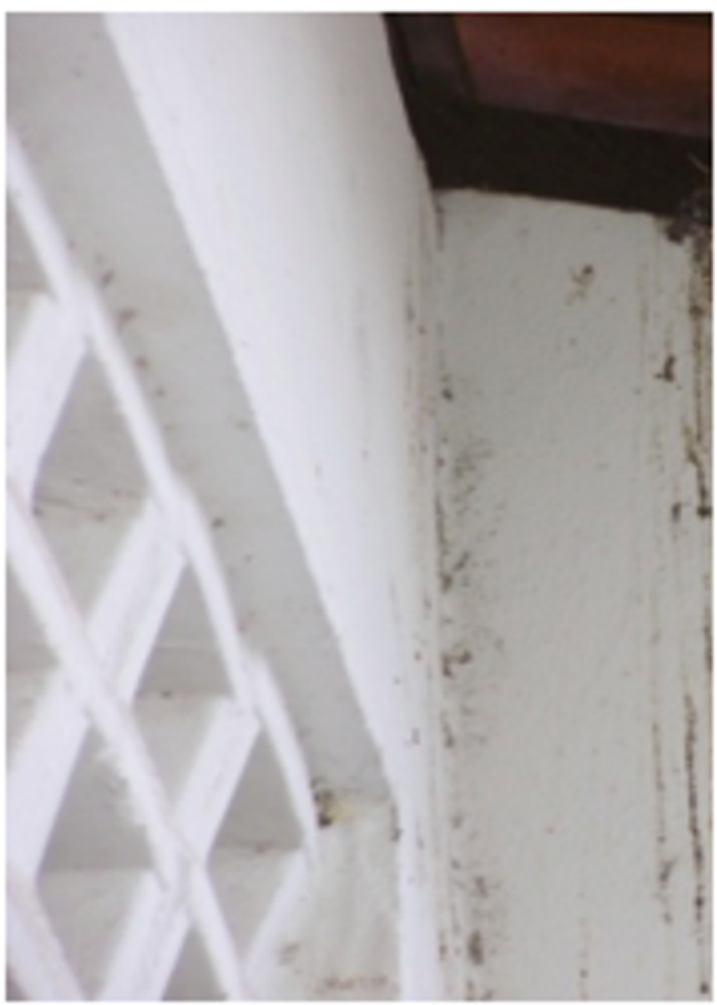

B

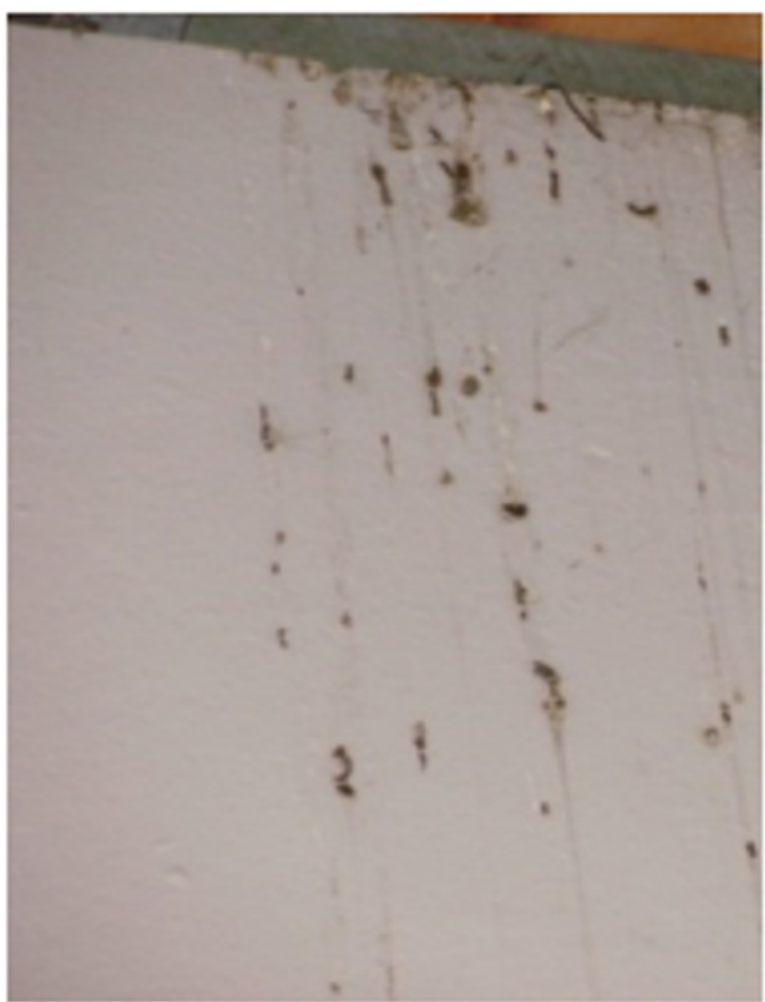

Figura 4 A e B: Fezes de pombos nas paredes de salas de aula e na área da cantina.

De acordo com relatos de funcionários antigos da escola, obtidos através de entrevistas, os pombos já estão presentes há muito tempo no local, provocando várias reclamações. Segundo uma funcionária que trabalha há mais de 15 anos na Instituição, existe muitos casos de alunos que solicitam a saída mais cedo da escola devido a mal-estar como náuseas e dores abdominais, fato que acredita ser decorrente da contaminação dos alimentos ingeridos pelos alunos na área do lanche. Ressaltamos que esses fatos não foram comprovados por exames médicos.

Uma das funcionárias da limpeza, que trabalha na escola há dois anos relata:

"Nós que trabalhamos na limpeza temos muito trabalho para limpar as sujeiras que os pombos fazem no chão da escola. Limpamos o local com água, sabão e água sanitária, mas só uma vez por semana. Nos outros dias nós só varremos porque não dá pra lavar a escola toda que é muito grande e são poucos funcionários que trabalham na limpeza". (Relato de entrevista de funcionária da limpeza, 2010).

Através desse relato podemos observar que a higienização da escola não é realizada corretamente, já que segundo Nunes e Miranda, (2010), a limpeza de forros, calhas ou qualquer local que apresente fezes, restos de ninho, ovos e penas, deve-se usar sempre luvas e máscara ou pano úmido sobre o nariz e a boca. Não se pode fazer remoção da sujeira a seco para evitar a inalação de poeira.

Outra funcionária entrevistada, uma das inspetoras que trabalha na escola desde a sua fundação, relata que 
a proliferação dos pombos aconteceu alguns anos após sua inauguração. Conta que já observou diversas vezes alunos alimentando os pombos com restos de lanches, principalmente as meninas. Como afirma a funcionária:

"Eu me preocupo muito com esses pombos, porque eles fazem sujeira na escola toda com as fezes e já li que tem várias doenças que são transmitidas pelos pombos. Já vi várias vezes os alunos se sujando quando encostam nas paredes sujas e também os pombos que ficam nos telhados dos corredores sujam os alunos que passam por baixo". (Relato de entrevista de funcionária da inspeção, 2010).

$\mathrm{Na}$ entrevista realizada com os alunos da escola, foram coletados dados com indivíduos da $5^{\mathrm{a}}$ a $8^{\mathrm{a}}$ séries, com idade variando de 10 a 16 anos. Foram aplicados 30 questionários com 8 perguntas. Na primeira, todos os alunos responderam que achavam importante estudar em uma escola limpa.

$\mathrm{Na}$ segunda pergunta, na qual os alunos foram indagados se costumavam jogar restos de lanches na escola, todos responderam que NÃO, mas foi constatado o contrário, já que foi observado que após o intervalo havia um acúmulo grande de restos de lanches espalhados pelo espaço escolar.

A Figura 5 apresenta os dados referentes ao conhecimento dos entrevistados em relação ao significado do termo Zoonoses. A maioria dos entrevistados (60\%) diz saber o que significa o termo em questão. Em entrevista semelhante, realizada no Parque Estadual Alberto Löfgren em São Paulo, Rodrigues (2009), comenta que alguns dos entrevistados acharam estranho os pombos estarem relacionados a zoonoses. 


\section{O que são Zoonoses?}

\section{IIM $\square \mathrm{NÃO}$}

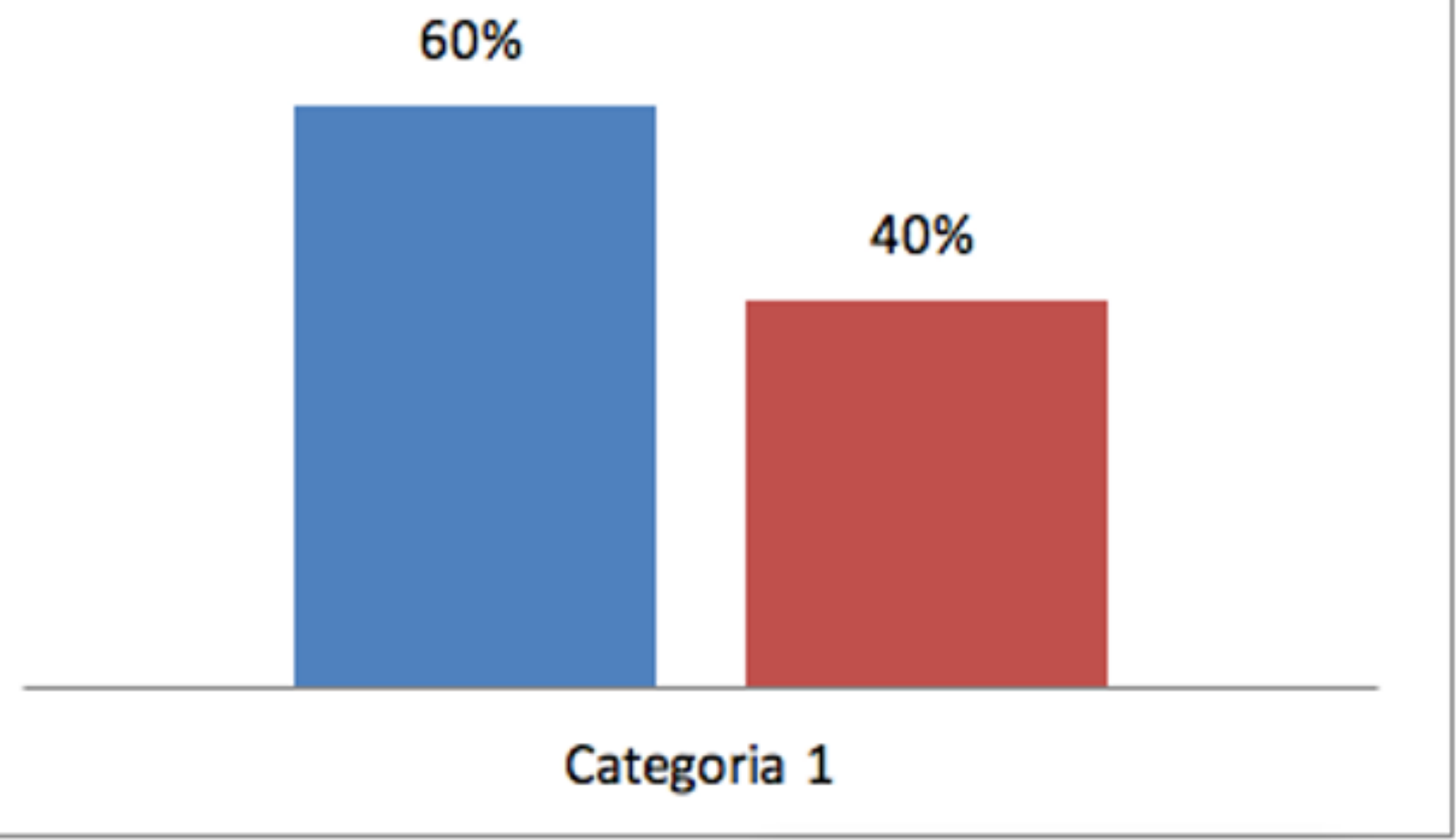

Figura 5: Opnião dos Alunos

Quando perguntados se os alunos se incomodavam com a presença de pombos na escola, cerca de $78 \%$ responderam que SIM, e destes $63 \%$ afirmaram que o incômodo se refere a sujeira ocasionada pelas fezes desses animais, $27 \%$ diz se preocupar com as doenças relacionadas a essas aves e $10 \%$ respondeu que se incomoda como o barulho que fazem nos forros das salas, atrapalhando a concentração na hora da aula. (Figura 6). 


\section{Você se incomoda com a presença de pombos na escola?}

\section{$\mathrm{SIM}=\mathrm{NÄO}$}

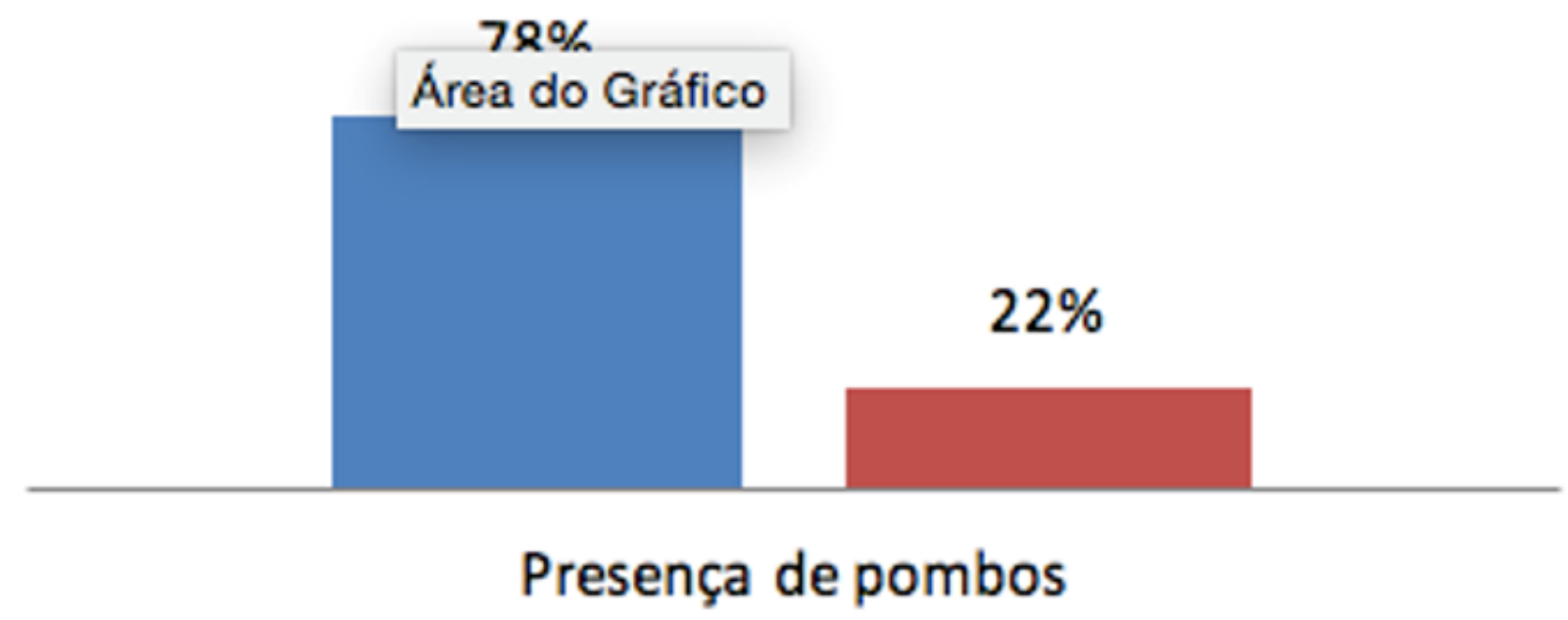

Figura 6: Opinião dos entrevistados se eles se incomodam com a presença de pombos.

A próxima pergunta realizada aos alunos era se eles achavam correto alimentar os pombos na escola. Muitos responderam que SIM (45\%). Alguns afirmam que sentem pena dos pombos, pois podem morrer sem alimentação, isso acaba atraindo um número cada vez maior dessas aves para o espaço escolar. (Figura 7). 


\section{Você acha correto alimentar os pombos?}

SIM $\square$ NÃO

$55 \%$

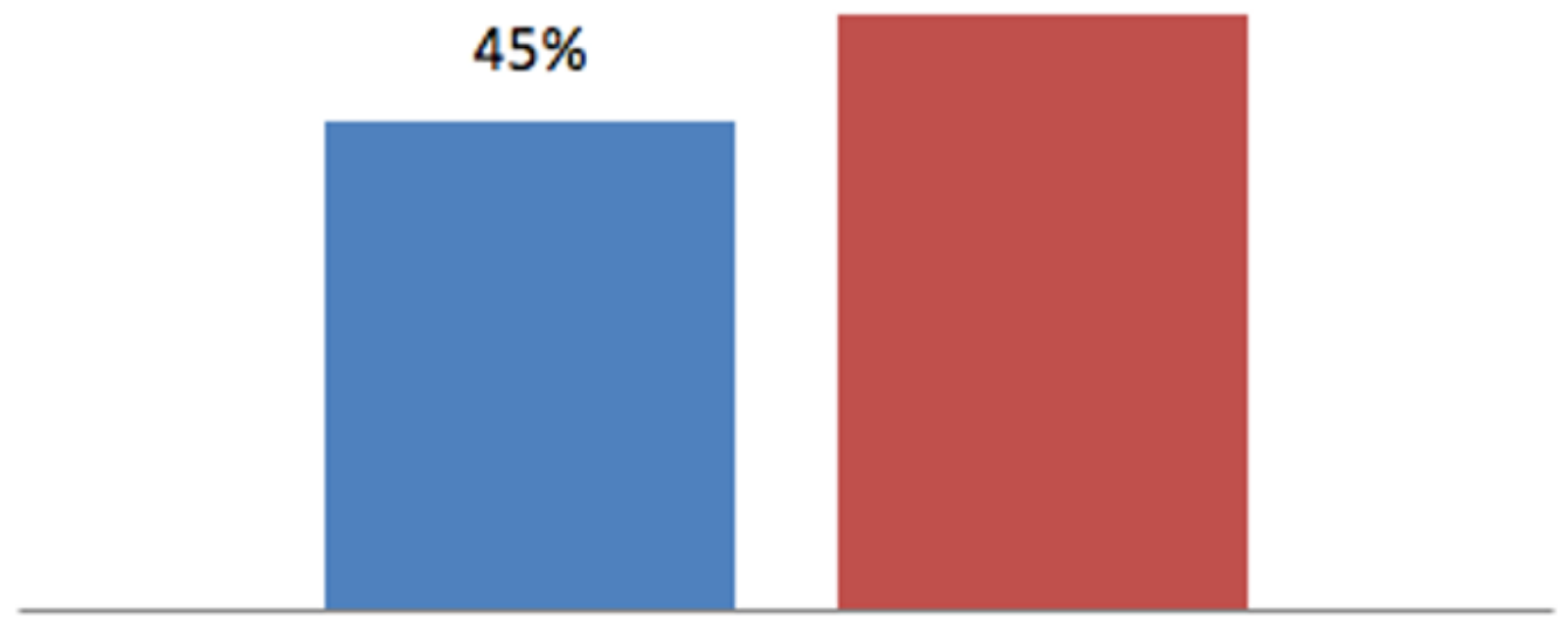

Alimentação

Figura 7: Opinião dos entrevistados spbre a alimentação dos pombos.

Ao serem questionados sobre o que deveria ser feito para evitar que essas aves permaneçam na escola, muitos alunos responderam que deveria se evitar jogar restos de lanches no chão, mantendo a escola sempre limpa (70\%), outros disseram que a solução seria colocar veneno para matar os pombos (12\%). Dos entrevistados, cerca de $15 \%$ acredita que destruindo os abrigos pode-se evitar a permanência das aves na escola e 3\% respondeu que uma medida eficaz seria colocar algum produto para afastar os pombos da escola. (Figura 8). 


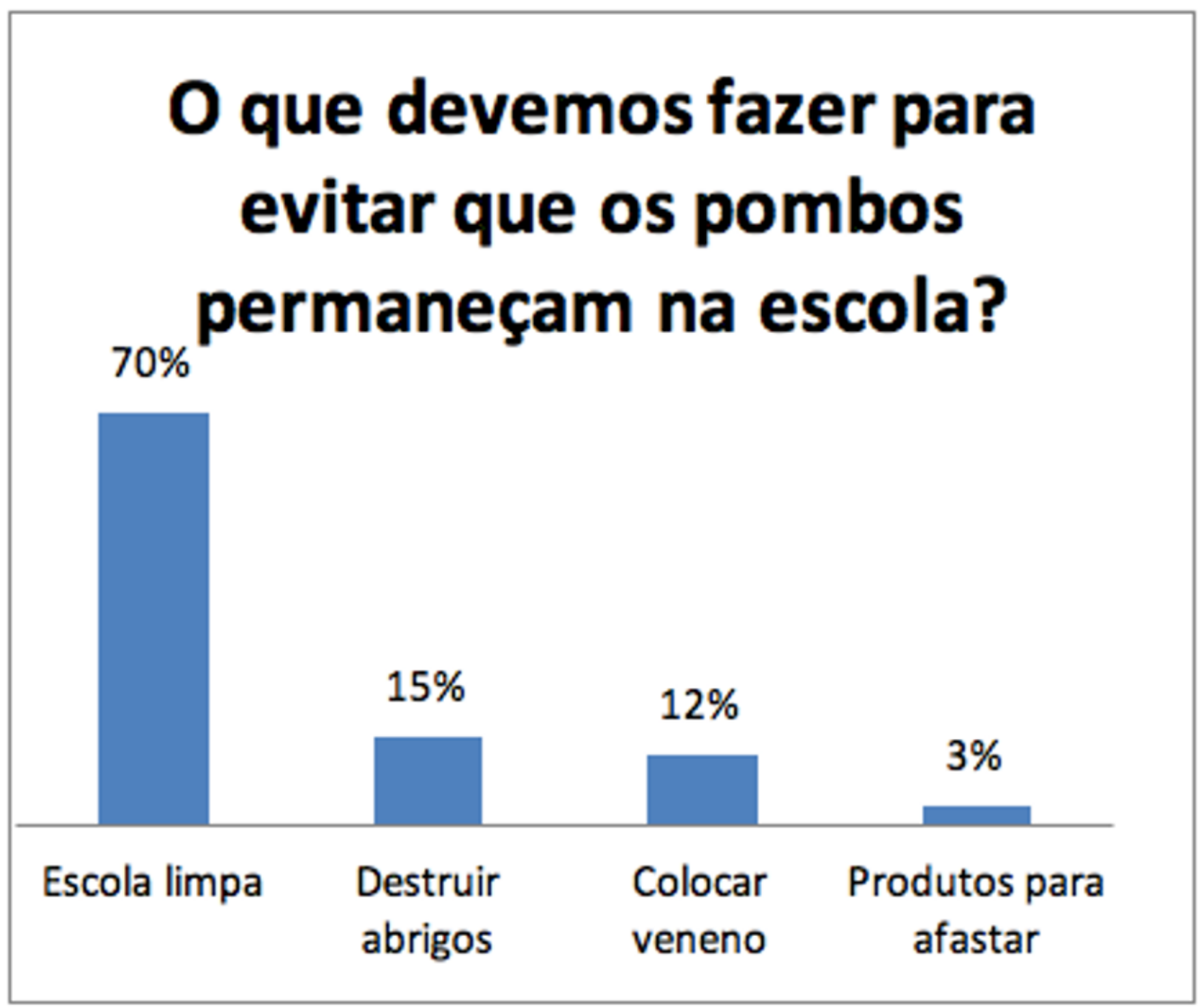

Figura 8: Opinião dos entrevistados a respeito de atitudes que devem tomar para evitar a permanência dos pombos na escola.

Com base nesses dados, é possível observar que para os alunos, a melhor medida para evitar que os pombos permaneçam na escola seria deixar o espaço sempre limpo para que não haja disponibilidade de alimentos.

Alguns alunos acreditam que colocando veneno na escola, alguns pombos morreriam e outros se afastariam, mas é importante lembrar que de acordo a portaria do IBAMA 29 de 24/3/94, o pombo é classificado como compondo a fauna brasileira e, portanto, passível de "abrigo legal" pela lei federal 9.605 de 1999, a lei de crimes ambientais. (NUNES, 2003).

Segundo Nunes, (2003) sem que se processe de forma adequada a eliminação das fontes de abrigo, água e alimentação destas aves, não teremos sucesso na sua eliminação de áreas alvo para o controle.

A partir dos dados obtidos nos questionários e em bibliografias consultadas, foram formuladas as 
palestras pelos alunos do $2^{\circ}$ ano (Figura 9 A e B). Estes enfatizam a importância da conscientização dos alunos e agentes de limpeza a respeito dos cuidados com a alimentação das aves e as doenças que elas podem transmitir. Para os agentes da limpeza, também deixaram claro a importância da limpeza dos locais sujos de fezes de pombos, utilizando água, sabão e água sanitária, bem como a utilização de luvas, botas e máscaras.

A

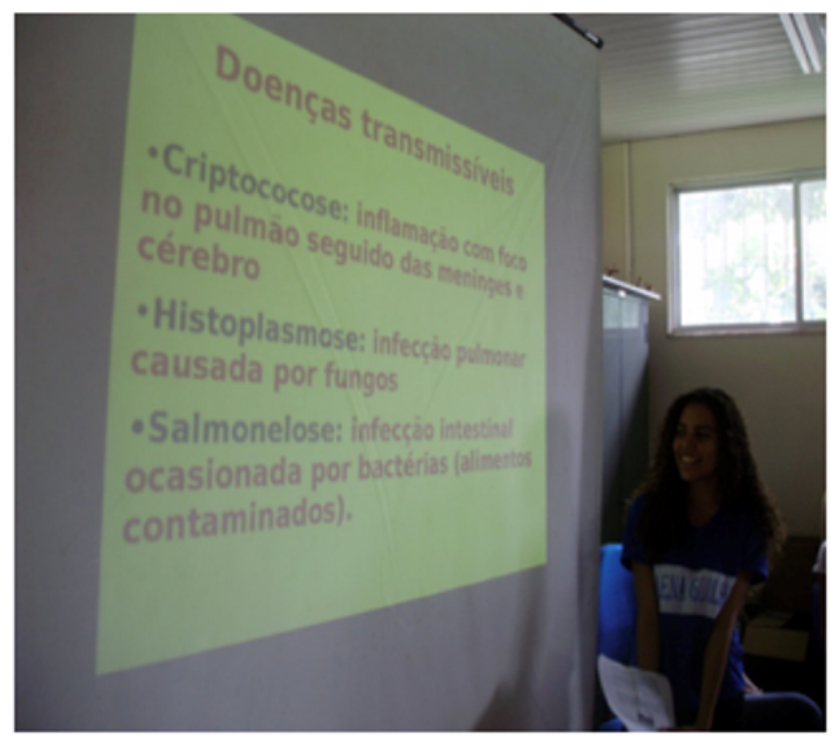

B

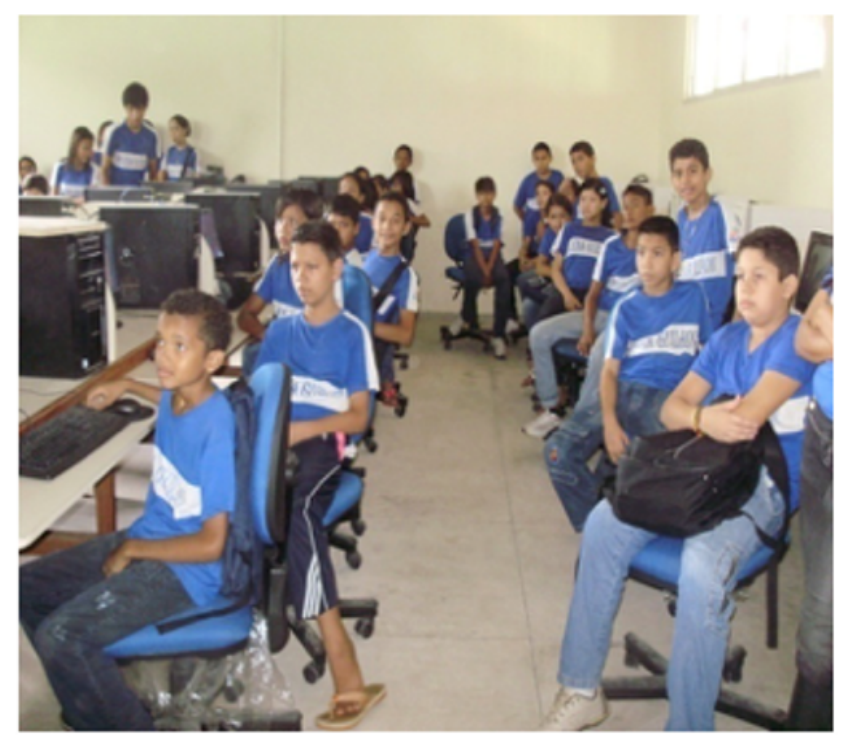

Figura 9 A e B: Aluno do $2^{\circ}$ ano realizando palestra para turma da $5^{\mathrm{a}}$ série.

Para finalização do trabalho de sensibilização, os alunos saíram em caminhada no entorno da escola, com a finalidade de esclarecer à comunidade sobre os cuidados que devem ter com relação aos pombos, evitando o contato com essas aves já que são transmissoras de diversos tipos de doenças. Foram entregues panfletos aos moradores com dicas de como evitar a proliferação desses animais, bem como as medidas para afastá-los de suas residências. (Figura 10 A, B e C). 
A

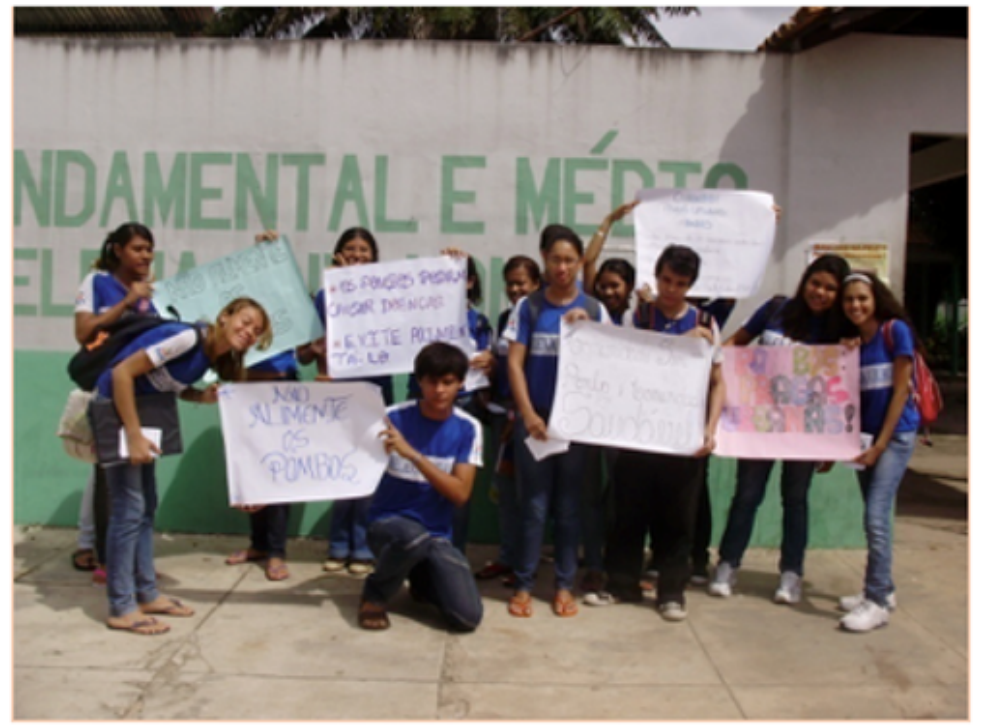

B

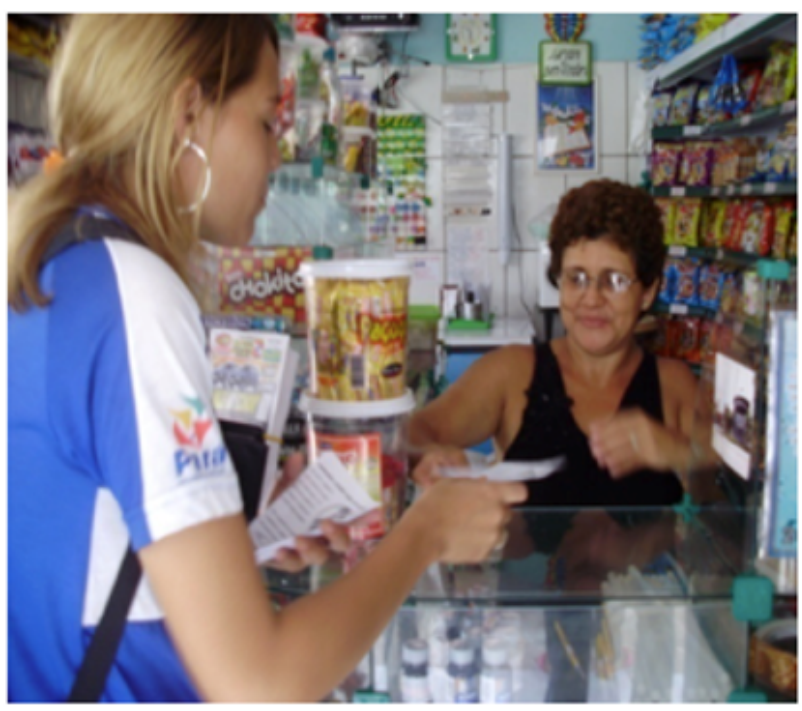

(c) $\mathbf{C}$

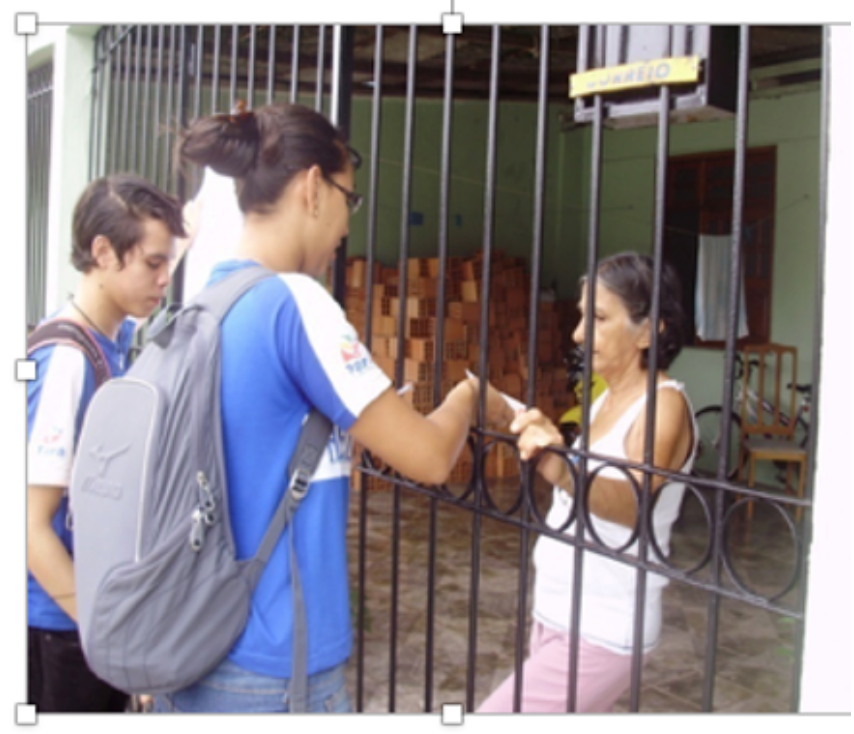

Figura 10 A, B e C: Alunos fazendo panfletagem no entorno da escola.

A ação educativa é de extrema relevância, pois a comunidade escolar deve ser informada a respeito da questão dos pombos domésticos, visando a mudança de hábitos. Esse trabalho de sensibilização deve ser contínuo, já que se trata de um problema sério de saúde pública.

\section{CONSIDERAÇÕES FINAIS}

O pombo doméstico é uma ave aparentemente inofensiva e que transmite pureza. É carregado de simbologias como a Paz, o Divino Espírito Santo e Amor. Não é um animal natural do Brasil, mas pela lei Federal do IBAMA, 9.605 de 12/02/98, são considerados espécimes da fauna silvestre, portanto 
protegidos de qualquer atitude que configure danos físicos ao animal. Esses animais se adaptaram muito bem em diversos ambientes, devido a fatores que propiciam a proliferação dos mesmos, tais como: alimento, abrigo e água. Sendo assim, essas aves se agrupam em determinados locais, causando transtornos à população local, principalmente transmissão de doenças e deterioração do patrimônio público.

Nesta perspectiva, o presente artigo procurou abordar a problemática da presença dos pombos no ambiente escolar, com o objetivo de despertar o interesse pela Educação Ambiental, de modo a criar uma mentalidade que propicie aos alunos um conhecimento específico do objeto estudado que abrange desde o conhecimento a respeito dos mecanismos que viabilizam a presença dessas aves no local em questão, perpassando aos problemas causados à saúde, bem como os modos de prevenção e controle desses animais.

Sendo assim, os objetivos propostos pelo presente trabalho fora alcançado parcialmente, da seguinte maneira. Primeiro trabalhamos as informações sobre as aves através de palestras, assim os alunos interagiram, tiraram dúvidas e ao final detectamos o nível de entendimento e aproveitamento dessa atividade, visto que, percebemos que os alunos compreenderam perfeitamente os mecanismos que colaboram para a permanência e proliferação dessas aves, bem como as doenças relacionadas aos pombos.

No entanto, a pesquisa em questão não nos proporcionou verificar a ocorrência de possíveis doenças relacionadas aos pombos, somente existem suposições, mas nada confirmado através de exames médicos.

$\mathrm{Na}$ análise dos questionários concluímos que a maioria dos alunos se incomoda com a presença dos pombos na escola, porém percebe-se que são os próprios estudantes que propiciam a permanência dessas aves no ambiente, já que espalham restos de alimentos por toda a escola. Outro fator observado é com relação à precária limpeza do ambiente escolar, verificando-se que somente a área da cantina é higienizada, porém esporadicamente.

Tendo em vista o acima citado, desenvolvemos a confecção e distribuição de panfletos informativos na escola e no entorno, para assim alcançar um dos objetivos do presente estudo que seria de propor soluções para o controle e prevenção e alertar sobre os riscos provenientes do contato com as aves. Portanto concluímos que o presente trabalho contribuiu para despertar nos alunos o senso de responsabilidade a respeito de atitudes que colaborem para minimizar os problemas ocasionados por essas aves.

\section{REFERÊNCIAS BIBLIOGRÁFICAS}

BENCKE, G. A. Pombos-domésticos, sugestões para controle em escolas públicas estaduais de Porto Alegre, 2007.

BRITO, R. Jornal O liberal. 14/01/11.

CORRÊA, M. P. S. Criptococose em crianças no Estado do Pará, Brasil. Revista sociedade Brasileira Medicina Tropical, Uberaba, 32(5): 505-508, set-out,1999.

CURY, G. C. Surto de histoplasmose em Pedro Leopoldo, Minas Gerais, Brasil, Revista da Sociedade 
Brasileira de Medicina Tropical, São Paulo, 34(5): 483-486, set-out, 2001.

FARIA, R. O.; NASCENTE. P. S.; MEINERZ. A. R.M.; CLEFT. M. B.; ANTUNES. T. A.; SILVEIRA. E. S.; NOBRE. M. O.; MEIRELES, M. C. A.; MELLO, J. R. B. Ocorrência de Cryptococcus neoformans em excretas de pombos na cidade de Pelotas, Estado do Rio Grande do Sul. Revista da Sociedade Brasileira de Medicina Tropical. 43 (2): 198 - 200, mar - abr, 2010.

INSTITUTO BRASILEIRO DOS RECURSOS NATURAIS RENOVÁVEIS - IBAMA, Fauna silvestre - acessado em 24/11/2010.

MOSCHIONI, C.; FARIA, H. P.; REIS, M. A. S.; SILVA, E. U. Pneumonia grave por Chlamydia psittaci. Jornal de Pneumologia. Vol. 27. n. 4. São Paulo. Jul / ago. 2001. Disponível em: <http:// www.scielo.br >. Acesso em: 15 jan. 2011.

NUNES, V. F. P. Pombos Urbanos: o desafio de controle. Instituto Biológico, São Paulo, v.65, n.1/2, p.89-92, jan./dez.,2003. Disponível em: 〈http://www.biologico.sp.gov.br >. Acesso em: 12 dez. 2010.

PEDRINI, A. de G. (org.). Metodologias em Educação Ambiental. Petrópolis: Vozes, 2002, p. 88-104.

QUEIROZ, J. P. A. F.; SOUSA, F. D. N.; LAGE, R. A.; IZAEL, M. DE A.; SANTOS, A. G. Criptococose - uma revisão bibliográfica. Acta Veterinária Brasileira, V. 2, n.2, p.32 - 38. 2008. Disponível em: <http://caatinga.ufersa.edu.br >. Acesso em: 10 jan. 2011.

SILVA, J. Associação Brasileira de Veterinários de Animais Selvagens. 2004.

SILVA, J. T. A representação social do pombo no meio urbano: o simbolismo na praça da Bandeira em Campina Grande, Paraíba. Dissertação de Mestrado, Curso de Desenvolvimento e Meio Ambiente: João Pessoa. 2006. Disponível em: <http://ufpb.br > Acesso em: 20 jan. 2011.

THOMAS, K. O Homem e o mundo natural: mudanças de atitude em relação às plantas e aos animais (1500-1800). Tradução: João Roberto Martins Filho. São Paulo: Cia das Letras, 1988, 454p.

UNIS. G., SILVA, V. B.; SEVERO, L. C. Histoplasmose disseminada e SIDA: importância do meio de cultivo para o espécime clínico-broncoscópico. Revista da Sociedade Brasileira de Medicina Tropical. Vol. 37 n.3. Uberaba - Mai/ Jun - 2004. Disponível em: 〈http://www.scielo.br >. Acesso em: 03 nov. 2010.

VALADARES, I. T. Pombos - Da história de Cher Ami à realidade portuária. Dissertação de mestrado, Curso de Educação Ambiental, Diretoria de Portos e Costas - Marinha do Brasil: Salvador. 2004. Disponível em: <http://www.dpc.mar.mil.br >. Acesso em: 10 nov. 2010.

[1] Licenciada em Biologia pela Universidade Federal do Pará. Professora da Rede Pública de Ensino. Concluinte do Curso de Especialização em Educação Ambiental e Uso dos Recursos Hídricos, FIBRA.

${ }^{[2]}$ Biólogo. Mestre em Biologia. Doutor em Medicina/Doenças Tropicais. Pesquisador do Programa de Pós Graduação do Núcleo de Medicina Tropical da UFPA. Professor em nível de graduação e Pós - 
Revista Científica Multidisciplinar Núcleo do Conhecimento - RC: 2712 - ISSN: 2448-0959

https://www.nucleodoconhecimento.com.br/saude/saude-na-presenca-de-pombos

graduação e Pesquisador na Universidade Federal do Pará - UFPA.

\section{PUBLIQUE SEU ARTIGO CIENTÍFICO EM:}

https://www.nucleodoconhecimento.com.br/enviar-artigo-cientifico-para-submissao 